\title{
ENTRY AGE INTO DAY CARE AND LATER DEVELOPMENT OF ALLERGIC DISORDERS - RESULTS FROM THE CITY OF LEIPZIG COHORT OF THE LISA STUDY
}

\author{
Stefan Röder ${ }^{1}$, Michael Borte ${ }^{23}$, Olf Herbarth ${ }^{1}$ on behalf of the LISA Study Group ${ }^{4}$ \\ ${ }^{1}$ Department of Human Exposure Research and Epidemiology; UFZ - Centre for Environmental Research Leipzig-Halle Ltd.; Leipzig, Germany \\ ${ }^{2}$ Department of Pediatrics, Municipal Hospital "St. Georg" Leipzig, Germany \\ ${ }^{3}$ Department of Pediatrics, University of Leipzig, Germany \\ ${ }^{4}$ The LISA Study Group is given in appendix
}

\section{SUMMARY}

The situation in early childhood is supposed to be a risk factor for later development of allergic diseases. The birth cohort from the LISA (Lifestyle - Immune System - Allergy) study gave us the opportunity to investigate the relationship between early childhood situation and the development of allergic diseases.

This paper describes our findings regarding to the relationship between entry age into day care and obstructive bronchitis as well as allergic rhinitis and atopic eczema.

Study was designed as a longitudinal birth cohort study. Children were examined by a physician at birth, $1 / 2$ year, 1 year, $1 \frac{1}{2}$ year, 2 years, 3 years and 4 years. Further information was collected using a structured questionnaire which was answered by the parents.

Outcomes under investigation were atopic eczema, allergic rhinitis, wheezing (with and without cold), obstructive bronchitis and asthma (after 2nd year of life).

Logistic regression analysis adjusted for infectious diseases of the mother during pregnancy, vaccination of the mother during pregnancy, antibiotics, prenatal smoking of the mother or other persons in the apartment and vaccination state showed an significant promoting effect of entry age into day care against obstructive bronchitis over the first three years of life (OR $1 / 2$ year: $8.55 ; 95 \% \mathrm{Cl}: 2.93 \ldots 24.97 ;$ OR 1 st year: $4.96 ; 95 \%$ $\mathrm{Cl}: 1.73 \ldots .14 .24 ;$ OR 2 nd year: $3.0695 \% \mathrm{Cl}: 1 \ldots 9.37)$. A further significant effect was found for crowding against asthma in the fourth year of life (OR 25.7; 95\% 1 Cl: $1.65 \ldots 400.17$ ).

No significant effects were found between the other periods under investigation (1st year until 4th year of life).

On the base of our findings we recommend an entry age into day care of more than six months to prevent effects shown.

Key words: atopic eczema, allergic rhinitis, wheezing, asthma, entry age into day nursery, crowding, logistic regression model

Address for correspondence: Stefan Röder, Department of Human Exposure Research and Epidemiology; UFZ - Centre for Environmental Research Leipzig - Halle Ltd.; Leipzig, 04301, Germany. E-mail: stefan.roeder@ufz.de

\section{INTRODUCTION}

Allergic diseases are common and appear to be increasing in prevalence over the past decades (1-4). Some authors report an increase in severity of these diseases $(5,6)$, whereas others report no further increase $(7,8)$.

Since Strachan (9) introduced the hygiene hypothesis in 1989, there were many attempts to verify this hypothesis. Illi et. al. (10) found a protective effect of running nose and other infectious diseases (excluding lower respiratory tract infections) against wheezing, asthma and bronchial hyperreactivity . Klinnert et. al. (11) showed a dependency between first year variables and school-age asthma support. Other publications investigated the relationship between entry age into day care, family size and later development of allergic diseases under the topic "hygiene hypothesis" (12-15). They concluded, that earlier exposure to allergens protects against atopy.
These reports guided us to the question: Can we reproduce similar effects using the data from the children in our LISA study?

The overall objective of the LISA (Lifestyle - Immune System - Allergy) study is to find reasons for atopic diseases. Atopy hereby refers to asthma, eczema, hay fever and other allergic disorders, which tends to accumulate within families (16).

In this paper we looked for a relationship between atopic situations (outcome variable) and the situation (independent variables) in early childhood. Independent variables under investigation were entry age into day care and crowding (person density in flats).

\section{MATERIALS AND METHODS}

\section{Study Design}

Investigations behind this paper are based on a subgroup (whose members were born and lived in the city of Leipzig, 
Germany) of the LISA study. It consists of 976 newborn infants (494 girls and 482 boys) from the same year of birth (1998). They were recruited by the LISA team in the main hospitals with obstetrics department in the German city of Leipzig. Local ethics committees guided the study.

Only healthy, fully developed children with German origin were included into study cohort. The following exclusion criteria were applied (17):

- birth prior to 37th week of pregnancy,

- birth weight less than $2500 \mathrm{~g}$,

- postnatal infection,

- dysplasia,

- mother with chronic disease or defect of the immune system,

- mother with persistent medication.

The cohort children were followed up at the age of $1 / 2,1,2,3$, 4 , and 6 years within 3 months of the child's birthday. The participation rate at the second birthday of the children was $86 \%$. All parents gave their consent before entering the study. Only 521 children had a complete longitudinal record. For all other children our data set missed one or more periods. Therefore the number of children differs in each period.

A questionnaire was sent to the parents together with an invitation for physical examination. The questionnaire consisted of the main topics "allergic heredity", "residential characteristics", "pregnancy", "feeding", "smoking/ETS", "allergic symptoms (respiratory, nasal, skin, physician diagnosis)", "pets", "socioeconomic family situation".

The physical examination of children took place close to their birthday in the respective year. This was done to exclude the effects of seasonal variations. During this examination the variables called "physicians diagnosis" were collected (17).

\section{Definition of Variables}

This section describes, how variables under investigation were defined. The description distinguishes between dependent variables (outcomes), independent variables and confounders.

\section{Dependent variables}

\section{Atopic eczema:}

According to the diagnostic criteria published by Hanifin and Rajka (18), a case was taken for as atopic eczema in the respective period, if there was skin rash with itch over more than 15 days at least on one of the following areas of the body:

- face, neck or nape;

- outer side of leg or arm;

- inner side of elbow or popliteus;

- hands or feet;

- at the trunk, not at the buttocks or

- other parts of the human body. Allergic rhinitis:

Allergic rhinitis was supposed to be true if a child had discomfort of runny nose in conjunction with tearing eyes in the respective period. It was defined from the period $1 \frac{1}{2}$ years onwards.

Wheezing (with/without cold):

If a child had wheezing over more than three days, we counted it as wheezing case in the respective period. We subdivided wheezing into wheezing with cold and wheezing without cold if there was/wasn't cold reported in conjunction with wheezing.

\section{Gastrointestinal infection:}

We used helminth infection as an indicator for gastrointestinal infection.

\section{Respiratory infection:}

Respiratory infection was considered in the respective period if there was pneumonia, pseudo-croup, pertussis or sinusitis present.

Obstructive bronchitis:

In contrast to wheezing, obstructive bronchitis was relied upon physicians diagnosis, if a physician gave the ICD-10-code (19) J45.9.

Asthma:

Because of the controversial definition of asthma in different sources $(16,20-25)$, we distinguished between obstructive bronchitis, which embraces the widely accepted clinical effect: airway obstruction (26) and asthma.

For the widely used atopic conditions urticaria and food-incompatibility we did not have the required variables for a consistent definition over all periods. Therefore these outcomes were not included in our longitudinal analysis.

\section{$\operatorname{IgE}$ :}

IgE was measured using a Pharmacia ImmunoCAP-FEIA-System. IgE-values below the lower detection threshold of $0.35 \mathrm{kU} / 1$ were set to a value of $0.175 \mathrm{kU} / 1$ (27). Values above the upper detection threshold of $5,000 \mathrm{kU} / 1$ were set to $5,000 \mathrm{kU} / 1$. We found a $90 \%$ percentile of $121 \mathrm{kU} / 1$ and a median of $19.3 \mathrm{kU} / 1$ at an age of two years in our cohort. Liappis et. al. found a reference value ( $90 \%$ percentile) for two years old children of up to $16 \mathrm{kU} / 1$ with a median of $6.62 \mathrm{kU} / 1$ (28). Because of the fact that Liappis et al. selected only children with absence of atopic heredity the values are not directly comparable. For better comparison we also did a selection for children with no atopic heredity and found $18.8 \mathrm{kU} / 1$ and a $90 \%$ percentile of $111 \mathrm{kU} / 1$. This difference is possibly influenced by a further selection criterion in the article of Liappis et al. which excluded children with increased IgE-level (which was not defined in detail) from their analysis.

Specific IgE:

We used specific IgE measurements as a further reference for allergic situation in our cohort. If there were the RAST Classes for HX2 or E1 or MX1 or FX5 or RX1 above zero then we concluded that the child was sensitized against a specific allergen and therefore we counted it in the respective variable.

\section{Independent variables}

We investigated entry age into day care and crowding as independent variables.

Entry age into day care:

We investigated the effect of entry age into day care on atopic situations because of the findings of Krämer et al.(14). They concluded that age of entry into day care affects the development of bronchitis.

Entry age into day care was subdivided into six classes: less than 6 months, 6 to 12 months, 12 to 18 months, 18 to 24 months, 24 to 36 months and more than 36 months.

\section{Crowding:}

Unlike Krämer et al., who defined crowding as more than three people living together in an apartment, we defined crowding as a binary variable derived from the family size.

Because of absence of a variable with information about the number of children in family, crowding was constructed using the 
variables "number of persons in household" and "marital status" respectively "living together with partner" in the following way: If "single mother/ father" was true then crowding was counted if more than 5 persons live together in one family (single mother/ father +4 children). In the case that both parents are living together in the family, we counted crowding with 6 and more persons in the family ( 2 parents +4 children).

\section{Confounders}

The following variables were taken into consideration as possible confounders:

- "allergic heredity" (29),

- "infectious diseases of the mother during pregnancy",

- "vaccination of the mother during pregnancy",

- "ingestion of antibiotics",

- "prenatal smoking of the mother or other persons in the apartment",

- "renovation of the apartment" and

- "vaccination state of the child".

All models in a longitudinal series were calculated with the whole set of confounders for comparability.

\section{Analysis}

Before analysis took place, pre-processing was carried out. This includes selecting, concatenating and recoding of original variable values into a uniform coding scheme for this analysis. This pre-processing was necessary because analysis was performed using data from different data sources (periods) with different coding schemes.

Each original variable was described with its data type, scale level and coding scheme. Based upon this meta data we are able to analyze the specification of each variable for concatenation and recode them to a common coding scheme. Furthermore constraints such as missing value codes or values outside specification have to be considered.

Odds ratios (OR) with 95\% confidence intervals were calculated to assess the risk estimates for allergic diseases. We performed stepwise logistic regression for each period in our longitudinal analysis with adjustment for the variables described in "Confounders". All results in this paper are based on a data set consisting of 976 children's data from birth to 4th year of life. In the case of missing data we deleted the entire case for the analysis in the respective period. If the significance level of the model (p) was 0.05 or less, then the model was judged to be significant.
All models were calculated with the cases which did not fulfil the criterion for the outcome variable as reference group. Therefore the results for a specified situation (outcome=true) have to be interpreted as referring to the cases which did not had this outcome (outcome $=$ false).

Statistical analysis was performed using Statistica release 6.1 from Statsoft Inc (Tulsa, OK, USA) (30).

We performed a longitudinal analysis for each outcome variable using each independent variable and using the described confounders. Longitudinal analysis was done using logistic regression models (31).

\section{RESULTS}

\section{Descriptive Statistics}

Table 1 shows the frequencies of outcome variables subdivided into overall frequency, frequency reported by parents and frequency reported by physician.

We observed a relatively constant behaviour of wheezing, a slight decrease in allergic rhinitis and in atopic eczema over the first two years of life. The prevalence of atopic eczema, obstructive bronchitis and asthma is increasing in the fourth year of investigation.

Respiratory infections were very common during the observed period, whereas gastrointestinal infections were very rare.

We observed a large number of children that first entered day care before their 2 nd year of life (42.1\%). Unfortunately we do not have exact information about the distribution of entry age into day care in the population. But we know that there is a difference between the eastern and western part of Germany. Early entry into day care is very common in the city of Leipzig as well as in the entire area of former East Germany. This may have historical reasons because in former East Germany working women were common practice. Therefore many day care centres in eastern part of Germany are able to assist babies and children with diapers.

To control unknown bias we analyzed known risk factors over all periods. Atopic heredity was counted if both parents had atopic symptoms in the past. With the variable smoking we controlled the bias of smoking during pregnancy (32). The variable "educational level of parents" was calculated for controlling the effect of different educational levels within the families (33). It refered to the achieved level of education in conjunction with the achieved level of professional training for both parents using the scheme in Table 2 (34).

Table 1. Period-prevalences of outcome variables (values are absolute numbers; percentages in parentheses) in the LISA study Leipzig, Germany 1998-2002

\begin{tabular}{|c|c|c|c|c|c|}
\hline $\begin{array}{ll}\text { Outcome } & \text { Age (years) }\end{array}$ & $\begin{array}{c}0.5 \\
n=849\end{array}$ & $\begin{array}{c}1 \\
n=820\end{array}$ & $\begin{array}{c}1.5 \\
\mathrm{n}=816\end{array}$ & $\begin{array}{c}2 \\
n=794\end{array}$ & $\begin{array}{c}4 \\
n=670\end{array}$ \\
\hline Atopic eczema & $84(9.9)$ & $104(12.7)$ & $114(14)$ & $144(18.1)$ & $93(13.9)$ \\
\hline Allergic rhinitis & $N / A^{*}$ & $\mathrm{~N} / \mathrm{A}$ & $22(2.7)$ & $19(2.4)$ & $15(2.2)$ \\
\hline Wheezing without cold & $15(1.77)$ & $7(0.8)$ & $1(0.1)$ & $10(1.3)$ & $11(1.6)$ \\
\hline Wheezing with cold & $60(7.1)$ & $85(10.4)$ & 90 (11) & $85(10.7)$ & $38(5.7)$ \\
\hline Gastrointestinal infection & $\mathrm{N} / \mathrm{A}$ & $0(0)$ & $4(0.4)$ & $3(0.3)$ & $16(1.6)$ \\
\hline Respiratory infection & $\mathrm{N} / \mathrm{A}$ & $573(69.9)$ & $648(79.4)$ & $640(80.6)$ & $561(57.5)$ \\
\hline Obstructive bronchitis & $\mathrm{N} / \mathrm{A}$ & $47(5.8)$ & $41(5)$ & $50(6.3)$ & $67(10)$ \\
\hline Asthma & $\mathrm{N} / \mathrm{A}$ & $\mathrm{N} / \mathrm{A}$ & $\mathrm{N} / \mathrm{A}$ & $1(0.1)$ & $7(1)$ \\
\hline
\end{tabular}

*N/A: not available; These values represent, that we did not have any child with this diagnosis. 
Table 2. Conversion scheme for the variable "educational level"

\begin{tabular}{|c|c|c|c|c|c|c|}
\hline \multicolumn{7}{|c|}{ Level of education } \\
\hline \multirow{7}{*}{ Level of professional training } & & $\begin{array}{l}\text { without } \\
\text { graduation }\end{array}$ & $\begin{array}{c}\text { secondary } \\
\text { school }\end{array}$ & O-level & $\begin{array}{c}\text { advanced } \\
\text { technical col- } \\
\text { lege entrance } \\
\text { qualification }\end{array}$ & $\begin{array}{l}\text { university-ent- } \\
\text { rance diploma / } \\
\text { A-level }\end{array}$ \\
\hline & without graduation & 1 & 2 & 3 & 5 & 6 \\
\hline & vocational school & 3 & 3 & 4 & 5 & 6 \\
\hline & technical school & 4 & 4 & 5 & 6 & 6 \\
\hline & university of applied sciences & $\mathrm{N} / \mathrm{A}$ & 7 & 7 & 7 & 7 \\
\hline & university & $\mathrm{N} / \mathrm{A}$ & 8 & 8 & 8 & 8 \\
\hline & other & 3 & 3 & 4 & 5 & 7 \\
\hline
\end{tabular}

Table 3. Period-prevalences of risks (values are absolute numbers; percentages in parentheses) in the LISA study Leipzig, Germany 1998-2002

\begin{tabular}{|l|c|c|c|c|c|}
\hline Risk Factor & $\mathbf{0 . 5}$ & $\mathbf{1}$ & $\mathbf{1 . 5}$ & $\mathbf{2}$ & $\mathbf{4}$ \\
$\mathrm{n}=\mathbf{8 1 6}$ & $\mathrm{n}=\mathbf{7 9 4}$ & $\mathrm{n}=670$ \\
\hline Atopic heredity & $81(9.5)$ & $78(9.5)$ & $82(10.0)$ & $80(10.1)$ & $64(9.6)$ \\
\hline Smoking & $153(18)$ & $138(16.8)$ & $135(16.5)$ & $133(16.8)$ & $102(15.2)$ \\
\hline Educational level of parents & $302(35.6)$ & $283(34.5)$ & $282(34.6)$ & $271(34.1)$ & $208(31)$ \\
\hline Renovation of apartment & $571(67.3)$ & $552(67.3)$ & $551(67.5)$ & $542(68.2)$ & $451(67.3)$ \\
\hline
\end{tabular}

Table 4. Odds ratios (95\% confidence intervals in parentheses) with significance levels of the independent variable (p) of obstructive bronchitis depending on entry age into day care (cases which did not fulfil the criterion for the outcome variable served as reference group for OR) in the LISA study Leipzig, Germany 1998-2002; models with statistically significant result are marked by italic font

\begin{tabular}{|c|c|c|c|c|c|c|}
\hline \multirow[t]{2}{*}{$\begin{array}{l}\text { Entry } \\
\text { age }\end{array}$} & & $\begin{array}{c}\text { Outcome obstructive } \\
\text { bronchitis } \\
1 / 2 \text { year }\end{array}$ & $\begin{array}{c}\text { Outcome obstructive } \\
\text { bronchitis } \\
1 \text { year }\end{array}$ & $\begin{array}{c}\text { Outcome obstructive } \\
\text { bronchitis } \\
1.5 \text { years }\end{array}$ & $\begin{array}{c}\text { Outcome obstructive } \\
\text { bronchitis } \\
2 \text { years } \\
\end{array}$ & $\begin{array}{c}\text { Outcome obstructive } \\
\text { bronchitis } \\
4 \text { years }\end{array}$ \\
\hline & Frequency & 47 & 47 & 41 & 50 & 67 \\
\hline 6 months & 44 & $\begin{array}{c}8.55 \\
(2.93 . .24 .97) \\
p<0.01\end{array}$ & $\begin{array}{c}4.96 \\
(1.73 . .14 .24) \\
p<0.01\end{array}$ & $\begin{array}{c}2.55 \\
(0.76 \ldots 8.58) \\
p=0.13\end{array}$ & $\begin{array}{c}3.06 \\
(1 \ldots 9.37) \\
p=0.05\end{array}$ & $\begin{array}{c}0.78 \\
(0.22 \ldots 2.81) \\
p=0.71\end{array}$ \\
\hline 12 months & 84 & $N / A$ & $\begin{array}{c}0.69 \\
(0.15 \ldots 3.16) \\
p=0.63\end{array}$ & $\begin{array}{c}1.09 \\
(0.32 \ldots 3.72) \\
p=0.89\end{array}$ & $\begin{array}{c}1.43 \\
(0.46 \ldots . .49) \\
p=0.54\end{array}$ & $\begin{array}{c}0.54 \\
(0.15 \ldots 1.88) \\
p=0.33\end{array}$ \\
\hline 18 months & 283 & $N / A$ & $N / A$ & $\begin{array}{c}0.87 \\
(0.37 \ldots 2.02) \\
p=0.74\end{array}$ & $\begin{array}{c}0.75 \\
(0.35 \ldots 1.61) \\
p=0.46\end{array}$ & $\begin{array}{c}1.25 \\
(0.67 \ldots 2.33) \\
p=0.48\end{array}$ \\
\hline 24 months & 4 & $\mathrm{~N} / \mathrm{A}$ & $\mathrm{N} / \mathrm{A}$ & $\mathrm{N} / \mathrm{A}$ & $\mathrm{N} / \mathrm{A}$ & $\mathrm{N} / \mathrm{A}$ \\
\hline 36 months & 178 & $N / A$ & $N / A$ & $\mathrm{~N} / \mathrm{A}$ & $\mathrm{N} / \mathrm{A}$ & $\begin{array}{c}1.06 \\
(0.54 \ldots 2.07) \\
p=0.86\end{array}$ \\
\hline
\end{tabular}

All values of 5 and above for at least one parent were counted as a high educational level within the family (confounder value $=0$ ). All other values were counted as low educational level (confounder value $=1$, which means additional risk).

Prevalences for confounding variables are shown in Table 3. We also computed a Mann-Whitney U-test for all periods, which had shown no significant differences between the risks in the respective periods.

We screened all periods which were covered by data from birth to 4 th year of life for significant models.

\section{Infections}

We used obstructive bronchitis as sign for infection in the lower respiratory tract. The adjusted OR for obstructive bronchitis had shown a significant decrease over the following periods for chil- dren with entry age into day care 6 months or less (Table 4).

We attribute these effects to the fact that the immune system of these young children is not able to defend against the enormous invasion of pathogens. Older children do not show this effect.

Stratification by sex discovered a difference between both sexes: boys showed the described relationship whereas in girls we did not come across models with this behaviour.

\section{Allergic Disorders}

Entry age into day care was used for describing the contact with other children and the associated influence onto the immune system.

We found significant effects for obstructive bronchitis and allergic rhinitis in relationship to the entry age into day nursery. The risk for obstructive bronchitis was significantly increased 
Table 5. Odds ratios (95\% confidence intervals in parentheses) with significance levels of the independent variable ( $p$ ) of allergic rhinitis depending on entry age into day care (cases which did not fulfil the criterion for the outcome variable served as reference group for OR) in the LISA study Leipzig, Germany 1998-2002; models with statistically significant result are marked by italic font

\begin{tabular}{|c|c|c|c|c|}
\hline \multirow[t]{2}{*}{$\begin{array}{l}\text { Entry } \\
\text { age }\end{array}$} & & $\begin{array}{c}\text { Outcome al- } \\
\text { lergic rhinitis } \\
1.5 \text { years }\end{array}$ & $\begin{array}{l}\text { Outcome al- } \\
\text { lergic rhinitis } \\
2 \text { years }\end{array}$ & $\begin{array}{l}\text { Outcome al- } \\
\text { lergic rhinitis } \\
4 \text { years }\end{array}$ \\
\hline & Frequency & 22 & 19 & 15 \\
\hline 6 months & 44 & $\mathrm{~N} / \mathrm{A}$ & $\begin{array}{c}0.95 \\
(0.11 \ldots 8.14) \\
p=0.96 \\
p(M)=0.58\end{array}$ & $\mathrm{~N} / \mathrm{A}$ \\
\hline 12 months & 84 & $\mathrm{~N} / \mathrm{A}$ & $\begin{array}{c}4.73 \\
(1.28 \ldots 17.5) \\
p=0.02\end{array}$ & $\begin{array}{c}2.07 \\
(0.4 \ldots 10.64) \\
p=0.38\end{array}$ \\
\hline 18 months & 283 & $\mathrm{~N} / \mathrm{A}$ & $\begin{array}{c}1.6 \\
(0.5 \ldots . .5 .12) \\
p=0.43\end{array}$ & $\begin{array}{c}1.14 \\
(0.34 \ldots 3.85) \\
p=0.83\end{array}$ \\
\hline 24 months & 4 & $\mathrm{~N} / \mathrm{A}$ & $N / A$ & $\mathrm{~N} / \mathrm{A}$ \\
\hline 36 months & 178 & $\mathrm{~N} / \mathrm{A}$ & $\mathrm{N} / \mathrm{A}$ & $\begin{array}{c}0.94 \\
(0.26 \ldots .3 .39) \\
p=0.92\end{array}$ \\
\hline
\end{tabular}

in the 1st and 2nd year of life if the children started their daily stay in day care until 6th month of life (see Table 4). The risk for allergic rhinitis was significant increased from in the 2 nd year of life if the children started their daily stay in day care until 12th month of life (Table 5).

The pattern of the relationship between atopic eczema (Table 6) and entry age into day care is nonlinear. In the first year of life we see a protective effect of day care. For later periods we see an increase of the OR in this relationship with its top in the 2nd year of life. This leads to the assumption, that there is a critical timeframe around the 1st birthday.

Stratification by sex discovered a difference between boys and girls. Boys showed behaviour similar to that of the whole cohort with higher absolute values, whereas in girls we did not find the described effects.

To prevent any misleading and to have real measures instead of answers to questions, we observed the behaviour of specific $\operatorname{IgE}$ in the 2nd year of life. Specific IgE level was constructed from the RAST classes of HX2 (house dust mite), E1 (cat dandruff), MX1 (mould), FX5 (food allergens) and RX1 (pollen). If one of these specific IgE had a RAST class more than zero the variable specific "IgE level raised" was supposed to be true. We found a significant model for entry age into day care between 12th and 18th month which was associated with 1.93 -fold $(95 \% \mathrm{CI}$ : $0.99 . .3 .77)$ risk for raised level of specific IgE in the 2nd year of life (see Table 7).

\section{Crowding}

We investigated all periods from $1 / 2$ year of life until 4 th year of life for a significant effect between atopic situations and crowding (number of children in an apartment). Crowding, which was found in 29 cases, showed a significant effect on the outcome asthma in the 4th year of life: OR was 25.7 ( $\mathrm{p}=0.02$ ) with an $95 \%$ CI from $1.65 \ldots 400.17$ (adjusted for infectious diseases during pregnancy, smoking during pregnancy, ingestion of antibiotics during of the child, vaccination state of the child, educational index of the parents, atopic heredity and renovation during pregnancy). The large confidence interval results from a relatively low number of asthma cases (only 7) in the 4th year of life. Because of the low case numbers and the large confidence interval, these findings are not suitable for recommendations.

\section{DISCUSSION AND RESULTS}

Entry age into day care was the exposure variable which yielded most significant models. Bias in this variable is unlikely because the information was collected directly in the questionnaire. This variable was collected in every relevant period.

The results of this study indicate that early entry into day care (up to 6th month of life) is positively associated with an increased risk of obstructive bronchitis in later childhood. For an entry

Table 6. Odds ratios (95\% confidence intervals in parentheses) with significance levels of the independent variable ( $p$ ) of atopic eczema depending on entry age into day care cases which did not fulfil the criterion for the outcome variable served as reference group for OR) in the LISA study Leipzig, Germany 1998-2002

\begin{tabular}{|c|c|c|c|c|c|c|}
\hline \multirow{2}{*}{$\begin{array}{l}\text { Entry } \\
\text { age }\end{array}$} & \multirow[b]{2}{*}{ Frequency } & $\begin{array}{l}\text { Outcome atopic } \\
\text { eczema } 1 \frac{1}{2} \text { year }\end{array}$ & $\begin{array}{l}\text { Outcome atopic } \\
\text { eczema } 1 \text { year }\end{array}$ & $\begin{array}{c}\text { Outcome atopic } \\
\text { eczema } 1.5 \text { years }\end{array}$ & $\begin{array}{l}\text { Outcome atopic } \\
\text { eczema } 2 \text { years }\end{array}$ & $\begin{array}{l}\text { Outcome atopic } \\
\text { eczema } 4 \text { years }\end{array}$ \\
\hline & & 84 & 104 & 114 & 144 & 93 \\
\hline 6 months & 44 & $\begin{array}{c}0.77 \\
(0.21 \ldots 2.82) \\
p=0.7\end{array}$ & $\begin{array}{c}0.88 \\
(0.28 \ldots . .2 .72) \\
p=0.82\end{array}$ & $\begin{array}{c}1.15 \\
(0.4 \ldots 3.28) \\
p=0.79\end{array}$ & $\begin{array}{c}1.16 \\
(0.44 \ldots . .09) \\
p=0.76\end{array}$ & $\begin{array}{c}0.53 \\
(0.06 \ldots . .4 .37) \\
p=0.56\end{array}$ \\
\hline 12 months & 84 & $N / A$ & $\begin{array}{c}1.04 \\
(0.43 \ldots 2.5) \\
p=0.93\end{array}$ & $\begin{array}{c}1.15 \\
(0.47 \ldots 2.78) \\
p=0.76\end{array}$ & $\begin{array}{c}1.36 \\
(0.63 \ldots 2.97) \\
p=0.43\end{array}$ & $\begin{array}{c}1.25 \\
(0.39 \ldots 3.95) \\
p=0.71\end{array}$ \\
\hline 18 months & 283 & $\mathrm{~N} / \mathrm{A}$ & $\mathrm{N} / \mathrm{A}$ & $\begin{array}{c}1.51 \\
(0.87 \ldots 2.64) \\
p=0.15\end{array}$ & $\begin{array}{c}0.98 \\
(0.58 \ldots 1.63) \\
p=0.93\end{array}$ & $\begin{array}{c}0.85 \\
(0.4 \ldots 1.78) \\
p=0.66\end{array}$ \\
\hline 24 months & 4 & $\mathrm{~N} / \mathrm{A}$ & $\mathrm{N} / \mathrm{A}$ & $\mathrm{N} / \mathrm{A}$ & $\mathrm{N} / \mathrm{A}$ & $\mathrm{N} / \mathrm{A}$ \\
\hline 36 months & 178 & $\mathrm{~N} / \mathrm{A}$ & $\mathrm{N} / \mathrm{A}$ & $\mathrm{N} / \mathrm{A}$ & $\begin{array}{c}0.91 \\
(0.53 \ldots 1.56) \\
p=0.72\end{array}$ & $\begin{array}{c}0.98 \\
(0.46 \ldots 2.11) \\
p=0.96\end{array}$ \\
\hline
\end{tabular}


Table 7. Odds ratios (95\% confidence intervals in parentheses) with significance levels of the independent variable $(p)$ of raised IgE level in the 2nd year of life depending on entry age into day care (cases which did not fulfil the criterion for the outcome variable served as reference group for OR) in the LISA study Leipzig, Germany 1998-2002; models with statistically significant result are marked by italic font

\begin{tabular}{|c|c|c|}
\hline \multirow[t]{2}{*}{$\begin{array}{c}\text { Entry } \\
\text { age }\end{array}$} & & $\begin{array}{l}\text { Specific lgE level } \\
\text { raised in the } \\
\text { 2nd year }\end{array}$ \\
\hline & Frequency & 77 \\
\hline 6 months & 44 & $\begin{array}{c}0.44 \\
(0.09 \ldots 2.08) \\
p=0.3\end{array}$ \\
\hline 12 months & 84 & $\begin{array}{c}0.42 \\
(0.09 \ldots 1.86) \\
p=0.25\end{array}$ \\
\hline 18 months & 283 & $\begin{array}{c}1.93 \\
(0.99 \ldots 3.77) \\
p=0.05\end{array}$ \\
\hline
\end{tabular}

age of more than 6 months there is no significant relation to the development of obstructive bronchitis verifiable.

Our cohort did not show a statistically significant dependency of atopic eczema on the entry age into day care. Although, we were able to show a non-significant relationship between entry age and atopic eczema, which corresponds with the results of many other published studies $(4,13,35)$.

For allergic rhinitis we found a significant model for entry age into day care vs. the development of allergic rhinitis in the 2nd year of life. Children who went into day care after the 6th and before the 12th month of life had four times higher risk for allergic rhinitis in the 2nd year of life than their contemporary which did not.

A drawback of the data behind this investigation is the lack in specificity of the outcome variables "obstructive bronchitis" and "asthma". "Obstructive bronchitis" stands for a number of conditions, which can but must not be described by the physician using this diagnose. Depending on the used definition "asthma" is not described in children below the age of four to five years. The prevalence of asthma in our data (see Table 1) reflects this fact. These outcomes are described here with a thorough documentation in mind, because we initially investigated both.

Another limitation of this analysis might be the frequent occurrence of missing values. Handling of them was different depending on the performed calculation. In some cases (i.e. calculation of life time prevalences) we set missing values to "no". In other cases (i.e. calculation of logistic regression models) we did a casewise deletion.

Our findings in this study indicate a relationship between entry age into day care which influences the development of obstructive bronchitis. Children which start their daily stay in day care early (prior to 6th month of life) have a significantly higher risk for the development of obstructive bronchitis. This finding conflicts with Strachan's hygiene hypothesis (9).

Opposite results were revealed by Krämer et. al. (14). In his view entry age into day nursery of 6 up to 11 months has a protective effect against atopy, which supports the hygiene hypothesis.
Van Schayck et.al. (36) analyzed three randomized clinical trials (37-39) and concluded that these trials have shown a relationship between allergen exposure reduction and a reduction in the development of allergy. This stands in contrast to the hygiene hypothesis, just like our findings concerning the relationship between crowding (more than 4 children in a family) on the development of asthma in the 4th year of life.

Svanes et al. (40) found a promoting effect of day care before age of 5 years against asthma in juvenile age. This result is not directly comparable with ours, because the observed range of age is different. In the context with the other findings of Svanes et al. that childhood exposure to other children in day care has a preventive effect against hay fever one can speculate, that there are possibly genetic factors which influence the development of allergic disorders. We suppose that these factors could affect the results of different studies in various ways so that conclusions of the authors of these papers differ.

This positive related effect of crowding on the development of atopic disorders (i.e. asthma) agrees with the results found by other studies regarding crowding and atopic situations (41-44). The findings of Golding et al. (45), von Mutius et al. (46) and (47) are in contradiction: they found a protective effect of crowding for asthma.

The main difference between the studies which found a protective effect and those who found a promoting effect is the geographical region and related with this the economic development status of the country. The cohorts of Golding et al. (UK), Mutius et al. (Germany) and Brabäck (Baltic region) live in Europe, whereas the probationers of Victora (Brazil), Cerqueiro (Argentina), Ballard (Kenya), Cardoso (Brazil) live in South America and Africa.

Obviously, the region and the status of economic development of a country plays a role in whether crowding has a promoting or protecting effect against atopic situations. This implicates that there must be hidden factors behind crowding.

Because of our relatively low number of cases we did not provide clear evidence in this area. Further investigations of this issue may be interesting. On the basis of our findings we recommend an entry age into day care to be more than six months to prevent effects shown.

\section{ACKNOWLEDGEMENT}

We thank all families for their participation in the LISA Study. The study was supported by grants of the Federal Ministry for Education, Science, Research and Technology (no. 01 EG 9705/2 and 01 EG 9732)

\section{APPENDIX}

The LISA study group:

GSF - National Research Center for Environment and Health, Institute of Epidemiology, Neuherberg (Wichmann HE, Heinrich J, Bolte G, Belcredi P, Jacob B, Schoetzau A, Mosetter M, Schindler J, Höhnke A); University of Leipzig, Department of Pediatrics (Borte M, Schulz R, Sierig G, Mirow K, Gebauer C, Schulze B), Institute of Clinical Immunology and Transfusion Medicine (Sack U, Emmrich F); Marien-Hospital Wesel, Department of Pediatrics (von Berg A, Schaaf B, Scholten C, Bollrath C); UFZ - Centre for Environmental Research Leipzig-Halle Ltd., Department of Human Exposure Research and Epidemiology (Herbarth O, Diez U, Lehmann I, Rehwagen M, Schlink U, Röder S); Ludwig-Maximilians-University Munich, Dr von Haunersches Kinderspital, Division of Pediatric Infectious Diseases and Immunology (Weiss M, Albert M); Friedrich-Schiller-University Jena, Institute of Clinical Immunology (Fahlbusch B), Institute of Occupational, Social and Environmental Medicine (Bischof W, Koch A). 


\section{REFERENCES}

1. Godard P. Epidemiology of allergic diseases. Res Immunol. 1998 MarApr;149(3):177-8.

2. Akinbami LJ, Schoendorf KC. Trends in childhood asthma: prevalence, health care utilization, and mortality. Pediatrics. 2002 Aug;110(2 Pt 1):315-22.

3. Brogger J, Bakke P, Eide GE, Johansen B, Andersen A, Gulsvik A. Long-term changes in adult asthma prevalence. Eur Respir J. 2003 Mar;21(3):468-72.

4. Levy RM, Gelfand JM, Yan AC. The epidemiology of atopic dermatitis. Clin Dermatol. 2003 Mar-Apr;21(2):109-15.

5. Russo MJ, McConnochie KM, McBride JT, Szilagyi PG, Brooks AM, Roghmann KJ. Increase in admission threshold explains stable asthma hospitalization rates. Pediatrics. 1999 Sep;104(3 Pt 1):454-62.

6. Williams H, Robertson C, Stewart A, Ait-Khaled N, Anabwani G, Anderson $\mathrm{R}$, et al. Worldwide variations in the prevalence of symptoms of atopic eczema in the International Study of Asthma and Allergies in Childhood. J Allergy Clin Immunol. 1999 Jan;103(1 Pt 1):125-38.

7. Ronchetti R, Villa MP, Barreto M, Rota R, Pagani J, Martella S, et al. Is the increase in childhood asthma coming to an end? Findings from three surveys of schoolchildren in Rome, Italy. Eur Respir J. 2001 May;17(5):881-6.

8. Braun-Fahrlander C, Gassner M, Grize L, Takken-Sahli K, Neu U, Stricker $\mathrm{T}$, et al. No further increase in asthma, hay fever and atopic sensitisation in adolescents living in Switzerland. Eur Respir J. 2004 Mar;23(3):407-13.

9. Strachan DP. Hay fever, hygiene, and household size. BMJ. 1989 Nov 18;299(6710):1259-60.

10. Illi S, von Mutius E, Lau S, Bergmann R, Niggemann B, Sommerfeld C, et al. Early childhood infectious diseases and the development of asthma up to school age: a birth cohort study. BMJ. 2001 Feb 17;322(7283):390-5.

11. Klinnert MD, Nelson HS, Price MR, Adinoff AD, Leung DY, Mrazek DA Onset and persistence of childhood asthma: predictors from infancy. Pediatrics. 2001 Oct;108(4):E69.

12. Strachan DP. Family size, infection and atopy: the first decade of the "hygiene hypothesis". Thorax. 2000 Aug;55 Suppl 1:S2-10.

13. Bodner C, Godden D, Seaton A; The Aberdeen WHEASE Group. Family size, childhood infections and atopic diseases. Thorax 1998 Jan;53(1):28-32.

14. Kramer U, Heinrich J, Wjst M, Wichmann HE. Age of entry to day nursery and allergy in later childhood. Lancet. 1999 Feb 6;353(9151):450-4.

15. Martinez FD, Wright AL, Taussig LM, Holberg CJ, Halonen M, Morgan WJ, et al. Asthma and wheezing in the first six years of life. N Engl J Med. 1995 Jan 19;332(3):133-8

16. Ciba Foundation Guest Symposium. Terminology definitions, classification of chronic pulmonary emphysema and related conditions. Thorax 1959;14:286-99.

17. Borte M, Schulz R, Lehmann I, et al. Influence of lifestyle and behaviour on the development of the immune system and allergic diseases. The LISA birth cohort study. In: Merker N, Göpfert P, Kirch W, editors. Public Health Research and Practice. Regensburg: S. Roderer Verlag; 2001. p. 59-77.

18. Hanifin JM, Rajka G. Diagnostic features of atopic-dermatitis. Acta Derm Venereol Suppl (Stockh). 1980; Suppl 92:44-7.

19. International Statistical Classification of Diseases and Related Health Problems: 10th Revision. 2nd ed. Geneva: World Health Organization 2004

20. Committee on Diagnostic Standards for Nontuberculous Respiratory Diseases, American Thoracic Society. Definitions and classification of chronic bronchitis, asthma, and pulmonary emphysema. Am Rev Respir Dis. 1962;85:762-8.

21. International consensus report on diagnosis and treatment of asthma Bethesda: National Heart, Lung, and Blood Institute, National Institutes of Health; 1992.

22. Hogg C, Bush A. Childhood asthma - all that wheezes is not inflammation Clin Exp Allergy. 1997 Sep;27(9):991-4.

23. Stevenson EC, Turner G, Heaney LG, Schock BC, Taylor R, Gallagher $\mathrm{T}$, et al. Bronchoalveolar lavage findings suggest two different forms of childhood asthma. Clin Exp Allergy. 1997 Sep;27(9):1027-35.

24. Haley KJ, Drazen JM. Inflammation and airway function in asthma: what you see is not necessarily what you get. Am J Respir Crit Care Med. 1998 Jan;157(1):1-3.

25. Crimi E, Spanevello A, Neri M, Ind PW, Rossi GA, Brusasco V. Dissociation between airway inflammation and airway hyperresponsiveness in allergic asthma. Am J Respir Crit Care Med. 1998 Jan;157(1):4-9.
26. Barnes PJ, Djukanovic R, Holgate ST. Pathogenesis. In: Brewis RAL, Corrin B, Geddes DM, Gibson GJ, editors. Respiratory medicine. London: Saunders; 1995. p. 1108-53.

27. Chan DW. General principles of immunoassay. In: Chan DW, Perlstein MT, editors. Immunoassay: a practical guide. Orlando: Academic Press; 1987. p. 71.

28. Liappis N, Schlebusch H, Niesen M. Referenzbereiche für die IgEKonzentration im Serum von Kindern. Monatsschr Kinderheilkd. 1992;140(5):300-2.

29. Kulig M, Bergmann R, Edenharter G, Wahn U; Multicenter Allergy Study Group.Does allergy in parents depend on allergy in their children? Recall bias in parental questioning of atopic diseases. J Allergy Clin Immunol. 2000 Feb;105(2 Pt 1):274-8.

30. STATISTICA für Windows [Software-System for data analysis] Version 6 [computer program]. 2004.

31. Hosmer DW, Jr., Lemeshow S. Applied logistic regression. 2nd ed. New York: John Wiley \& Sons; 2000.

32. Gilliland FD, Berhane K, McConnell R, Gauderman WJ, Vora H, Rappaport EB, et al. Maternal smoking during pregnancy, environmental tobacco smoke exposure and childhood lung function. Thorax. 2000 Apr;55(4):271-6.

33. Heinrich J, Popescu MA, Wist M, Goldstein IF, Wichmann HE. Atopy in children and parental social class. Am J Public Health. 1998 Sep;88(9):1319-24.

34. Hoffmeyer-Zlotnik J. „Beruf“ und „Stellung im Beruf“ als Indikatoren für soziale Schichtung. In: Ahrens W, Bellach BM, Jöckel KH, editors. Messung soziodemographischer Merkmale in der Epidemiologie. RKISchriften 1/98. München: MMV Medizin-Verlag; 1998. p. 54-64.

35. Austin JB, Kaur B, Anderson HR, Burr M, Harkins LS, Strachan DP, et al. Hay fever, eczema, and wheeze: a nationwide UK study (ISAAC, international study of asthma and allergies in childhood). Arch Dis Child. 1999 Sep;81(3):225-30.

36. van Schayck CP, Knottnerus JA. Can the 'hygiene hypothesis' be explained by confounding by behavior? J Clin Epidemiol. 2004 May;57(5):435-7.

37. Arshad SH, Matthews S, Gant C, Hide DW. Effect of allergen avoidance on development of allergic disorders in infancy. Lancet. 1992 Jun 20;339(8808):1493-7.

38. Chan-Yeung M, Manfreda J, Dimich-Ward H, Ferguson A, Watson W, Becker A. A randomized controlled study on the effectiveness of a multifaceted intervention program in the primary prevention of asthma in high-risk infants. Arch Pediatr Adolesc Med. 2000 Jul;154(7):657-63.

39. Custovic A, Simpson BM, Simpson A, Kissen P, Woodcock A; NAC Manchester Asthma and Allergy Study Group. Effect of environmental manipulation in pregnancy and early life on respiratory symptoms and atopy during first year of life: a randomised trial. Lancet. $2001 \mathrm{Jul}$ 21;358(9277):188-93.

40. Svanes C, Jarvis D, Chinn S, Omenaas E, Gulsvik A, Burney P, et al. Early exposure to children in family and day care as related to adult asthma and hay fever: results from the European Community Respiratory Health Survey. Thorax. 2002 Nov;57(11):945-50.

41. Victora CG, Smith PG, Barros FC, Vaughan JP, Fuchs SC. Risk factors for deaths due to respiratory infections among Brazilian infants. Int J Epidemiol. 1989 Dec;18(4):918-25.

42. Cerqueiro MC, Murtagh P, Halac A, Avila M, Weissenbacher M. Epidemiologic risk factors for children with acute lower respiratory tract infection in Buenos Aires, Argentina: a matched case-control study. Rev Infect Dis. 1990 Nov-Dec;12 Suppl 8:S1021-8.

43. Ballard TJ, Neumann CG. The effects of malnutrition, parental literacy and household crowding on acute lower respiratory infections in young Kenyan children. J Trop Pediatr. 1995 Feb;41(1):8-13.

44. Cardoso MR, Cousens SN, de Goes Sigueira LF, Alves FM, D’ Angelo LA. Crowding: risk factor or protective factor for lower respiratory disease in young children? BMC Public Health. 2004 Jun 3;4:19.

45. Butler NR, Golding J, Howlett, B, editors. From birth to five: a study of the health and behaviour of Britain's five year olds. Oxford: Pergamon; 1986.

46. von Mutius E, Martinez FD, Fritzsch C, Nicolai T, Reitmeir P, Thiemann HH. Skin test reactivity and number of siblings. BMJ. 1994 Mar 12;308(6930):692-5

47. Brabäck L, Breborowicz A, Julge K, Knutsson A, Riikjarv MA, Vasar M, et al. Risk factors for respiratory symptoms and atopic sensitisation in the Baltic area. Arch Dis Child. 1995 Jun;72(6):487-93.

Received September 1, 2005

Received in revised form and accepted January 30, 2006 